\title{
Pemphigus vegetans - possible association with enalapril
}

\section{Pęcherzyca bujająca o możliwym związku z terapią enalaprylem}

Paulina Barasińska', Natalia Noga', Beata S. Bergler-Czop², Jakub Sazanów-Lubelski', Kornelia Pietrauszka², Ligia Brzezińska-Wcisło²

\author{
'Dermatology and STD Ward, Municipal Hospital, Sosnowiec, Poland \\ 2Department of Dermatology, Medical Faculty in Katowice, Silesian Medical University in Katowice, Poland \\ ${ }^{3}$ The Student's Science Club by the Department of Dermatology, Medical University in Katowice, Poland \\ 'Oddział Skórno-Wenerologiczny Szpitala Miejskiego w Sosnowcu, Polska \\ 2Katedra i Klinika Dermatologii Wydziału Lekarskiego w Katowicach Śląskiego Uniwersytetu Medycznego w Katowicach, Polska \\ ${ }^{3}$ Studenckie Koło Naukowe przy Katedrze i Klinice Dermatologii Śląskiego Uniwersytetu Medycznego w Katowicach, Polska
}

CORRESPONDING AUTHOR/ ADRES DO KORESPONDENCJI:

Paulina Barasińska

Oddział Skórno-Wenerologiczny

Szpital Miejski

ul. Szpitalna 1

41-219 Sosnowiec, Poland

tel.: +48609282073

e-mail: paulina.barasinska@ gmail.com

\begin{abstract}
Introduction. Pemphigus vegetans is the least common form of pemphigus. Typical clinical presentation of the condition involves blisters transforming into papillous or pustular eruptions. Treatment consists of administration of systemic glucocorticosteroids as a monotherapy, or combined with immunosuppressants.
\end{abstract}

Objective. Presentation of a case of pemphigus vegetans of possible drug-induced aetiology and severe course.

Case report. A 58-year old man was admitted with papillous lesions persisting for few weeks in the anogenital area, axillae and ear lobes. For several months the man has been using the hypotensive medication - enalapril. Pemphigus vegetans was diagnosed based on the clinical presentation and the immunopathological examination. Enalapril was discontinued and prednisone was introduced at the maximum dose of $2 \mathrm{mg} / \mathrm{kg} /$ day, with subsequent improvement of the condition. Considering adverse effects of chronic glucocorticosteroid therapy, azathioprin was also introduced at the dose of $50 \mathrm{mg}$ /day, with gradual reduction of the prednisone dose over time. The patient in good general and local condition remains under supervision of a dermatologist.

Conclusions. A case of a patient is presented with lesions initially suggesting papillary pyroderma. As a result of rapid progression the disease significantly hindered the patient's everyday functioning. Pemphigus vegetans in this patient may have been induced by enalapril.

\section{STRESZCZENIE}

Wprowadzenie. Pęcherzyca bujająca jest najrzadszą postacią pęcherzycy. Charakterystycznym obrazem klinicznym są pęcherze przekształcające się w brodawkujące lub krostkowe wykwity. Leczenie polega na podawaniu ogólnie glikokortykosteroidów w monoterapii lub z lekami immunosupresyjnymi.

Cel pracy. Przedstawienie przypadku pęcherzycy bujającej o możliwej etiologii polekowej i ciężkim przebiegu. 
Opis przypadku. Mężczyzna 58-letni został przyjęty do szpitala z utrzymującymi się od tygodni zmianami brodawkującymi w okolicy krocza, dołów pachowych i małżowin usznych. Od kilku miesięcy przyjmował lek hipotensyjny - enalapryl. Na podstawie obrazu klinicznego oraz badania immunopatologicznego rozpoznano pęcherzycę bujającą. Odstawiono enalapryl i włączono prednizon w dawce maksymalnej $2 \mathrm{mg} / \mathrm{kg}$ m.c., uzyskując poprawę stanu miejscowego. Ze względu na działania niepożądane przewlekłej glikokortykosteroidoterapii dołączono azatioprynę $\mathrm{w}$ dawce $50 \mathrm{mg} /$ dobę, stopniowo redukując dawkę prednizonu. Pacjent w dobrym stanie ogólnym i miejscowym jest pod stałą opieką dermatologiczną.

Wnioski. Przedstawiono pacjenta ze zmianami początkowo sugerującymi piodermię brodawkującą o powolnym przebiegu, a następnie w wyniku gwałtownej progresji znacznie utrudniającymi codzienne funkcjonowanie pacjenta. Pęcherzyca bujająca u tego pacjenta mogła zostać wyindukowana enalaprylem.

Key words: autoimmune diseases, azathioprin, pemphigus vegetans, desmoglein.

Słowa kluczowe: choroby autoimmunologiczne, azatiopryna, pęcherzyca bujająca, desmogleina.

\section{INTRODUCTION}

Pemphigus vegetans is a rare form of pemphigus vulgaris, constituting $1-2 \%$ of all pemphigus cases [1]. The condition is characterised by formation of intraepidermal blisters resulting from broken connection between epidermal cells separated in course of acantholysis caused by presence of pathogenic auto-antibodies and bound in vivo in intercellular spaces of the epidermis [2]. Bullous diseases may be also caused by a broad selection of medications. Some of them are: angiotensin convertase enzyme (ACE) inhibitors: captopril, enalapril, ramipril, and drugs containing the thiol group, where oxygen atom of the hydroxyl group was substituted by sulphur atom, as in penicillamines, panicillin derivaties, piroxicam, thiamazole, and also by a phenol group, such as aspirin, cephalosporins, rifampicin, levodopa, heroine, phenobarbital. Lesions may be also provoked by: propranolol, nifedypine, isotretinoin and nonsteroidal anti-inflammatory drugs (NSAIDs). Up to $30 \%$ of patients with drug-induced pemphigus require immunosuppressive treatment, despite discontinuation of the drug causing the disease [3] There are to varieties of phemphigus vegetans: the more common Neumann disease, characterised by expanding and combining blisters transforming into dry, papillous and hyperkeratotic outgrowths, and Hallopeau disease, characterised by pustular eruptions [4]. The disease is typically localised in axillae, groins, the area of the anus and sexual organs, as well as in nasolabial folds and mouth corners. Diag-

\section{WPROWADZENIE}

Pęcherzyca bujająca jest rzadką odmianą pęcherzycy zwykłej, stanowiącą 1-2\% wszystkich przypadków pęcherzycy [1]. Charakteryzuje się powstawaniem śródnaskórkowych pęcherzy wskutek utraty łączności pomiędzy komórkami naskórka w procesie akantolizy, wywołanym obecnością patogennych autoprzeciwciał w krążeniu oraz związanych in vivo w przestrzeniach międzykomórkowych naskórka [2]. Choroby pęcherzowe mogą być również wywołane przez liczne leki. Należą do nich inhibitory konwertazy angiotensyny (ACE), takie jak kaptopryl, enalapryl, ramipryl, oraz leki zawierające grupę tiolową, w której atom tlenu grupy hydroksylowej został zastąpiony atomem siarki, takie jak penicylaminy, pochodne penicyliny, piroksykam, tiamazol, a także leki zawierające grupę fenolową, takie jak kwas acetylosalicylowy, cefalosporyny, ryfampicyna, lewodopa, heroina, fenobarbital. Zmiany mogą także prowokować propranolol, nifedypina, izotretynoina i niesteroidowe leki przeciwzapalne (NLPZ). Do 30\% chorych na pęcherzycę indukowaną lekami wymaga leczenia immunosupresyjnego pomimo odstawienia wywołującego leku [3]. Wyróżnia się dwie odmiany pęcherzycy bujającej: częściej występującą odmianę Neumanna charakteryzującą się rozszerzającymi i łączącymi się pęcherzami, które przekształcają się w suche, brodawkujące, hiperkeratotyczne twory, oraz typ Hallopeau cechujący się wykwitami krostkowymi [4]. Choroba lokalizuje się najczęściej w dołach pachowych, pachwinach, okolicach odbytu i narządów płciowych, fałdach nosowo- 
nostics is based on detection of intracellular bound IgG antibodies in a direct immunopathological investigation of the serum, demonstrating circulating auto-antibodies against desmoglein 3 and/or 1 . Glucocorticosteroids combined with immunosuppressants (usually asathioprin) are mostly used for treatment of phemphigus [1, 2].

\section{OBJECTIVE}

We present the case of a 58-year old male patient with highly intensified lesions in course of phemphigus vegetans of possible drug-induced aetiology, who had been for several months treated with topical formulas, with no improvement. Several weeks before admission to the hospital, where a correct diagnosis was made, the patient experienced a highly rapid progression of pathological eruptions - a significant extension of the occupied area, occupation of mucosa and scalp.

\section{CASE REPORT}

The 58-year old male patient, with history of arterial hypertension, peptic ulcer disease and degenerative spinal disease, for several months using enapril and for several weeks using hydroxyzine and estazolam, was admitted to the Dermatology Ward for diagnostics and treatment of extensive dermatological lesions in the area of sexual organs and crotch, reaching the lower part of the hypogastrium, persisting for several months. The patient denied using any other medication. Half a year before the patient was treated for papillous pyroderma of the area of sexual organs. Two months before the admission the patient observed a significant progression of skin eruptions. Physical examination at admission demonstrated hypertrophic, thick papillous lesions with increased cohesion and dark pigmentation, with a dry and hyperkeratotic surface, sharply demarcated from the surrounding skin, localised on sexual organs and surrounding skin in the crotch, the lower part of the hypogastrium and linea alba, in the area of the anus, behind ears and in the left axilla. An erosion, approx. $7 \mathrm{~cm}$ in diameter, was visible on the scalp. It was covered by a significant amount of purulent secretion. Fine erosions were present on oral mucosa and in the nasal vestibule. Numerous erythematous eruptions were disseminated over the patient's back. Lymph nodes were unpalpable. Other organs and systems were unremarkable. Dermatological symptoms were accompanied by pruritus affecting night sleep, and persisting despite the use of medication (hydroxyzine, estazolam) (figs 1, 2). -wargowych i kącikach ust. Diagnostyka opiera się na stwierdzeniu związanych śródkomórkowo przeciwciał IgG w bezpośrednim badaniu immunopatologicznym oraz na badaniu immunologicznym surowicy, w którym stwierdza się krążące autoprzeciwciała skierowane przeciwko desmogleinie $3 \mathrm{i} /$ lub 1 . W leczeniu pęcherzycy stosuje się głównie glikokortykosteroidy w skojarzeniu z lekami immunosupresyjnymi, najczęściej azatiopryną $[1,2]$.

\section{CEL PRACY}

Przedstawiamy przypadek 58-letniego mężczyzny $\mathrm{z}$ bardzo nasilonymi zmianami w przebiegu pęcherzycy bujającej o możliwej etiologii polekowej, który przez kilka miesięcy był leczony objawowo preparatami miejscowymi bez żadnej poprawy. Kilka tygodni przed hospitalizacją, w trakcie której postawiono prawidłową diagnozę, nastąpiła bardzo szybka progresja wykwitów chorobowych - znaczne zwiększenie obszaru zmian skórnych oraz zajęcie śluzówek i owłosionej skóry głowy.

\section{OPIS PRZYPADKU}

Mężczyzna 58-letni, w wywiadzie z nadciśnieniem tętniczym, chorobą wrzodową żołądka i chorobą zwyrodnieniową kręgosłupa, przyjmujący na stałe od kilku miesięcy enalapryl i od kilku tygodni hydroksyzynę i estazolam, został przyjęty na oddział dermatologiczny w celu rozpoznania i leczenia utrzymujących się od kilku miesięcy rozległych zmian skórnych okolicy narządów płciowych i krocza, sięgających dolnej części podbrzusza. Pacjent nie przyjmował innych leków. Pół roku wcześniej był leczony z rozpoznaniem piodermii brodawkującej okolic narządów płciowych. Dwa miesiące przed hospitalizacją pacjent zauważył znaczną progresję wykwitów skórnych. Przy przyjęciu na oddział w badaniu przedmiotowym stwierdzono przerosłe, grube zmiany brodawkujące o wzmożonej spoistości i ciemnym zabarwieniu, z suchą, hiperkeratotyczną powierzchnią, ostro odgraniczone od otoczenia, zlokalizowane na narządach płciowych i otaczającej skórze krocza, dolnej części podbrzusza i kresie białej, w okolicy odbytu, za uszami i w lewym dole pachowym. Na owłosionej skórze głowy widoczna była nadżerka średnicy ok. $7 \mathrm{~cm}$, pokryta znaczną ilością ropnej wydzieliny, na śluzowce jamy ustnej i w przedsionku nosa obecne były drobne nadżerki. Na plecach występowały rozsiane wykwity rumieniowe. Węzły chłonne były niebadalne, pozostałe narządy i układy - bez zmian. Objawom skórnym towarzyszył znacznie nasilony świąd, uniemożliwiający ciągły sen, pomimo stosowania leków (hydroksyzyna, estazolam) (ryc. 1, 2). 

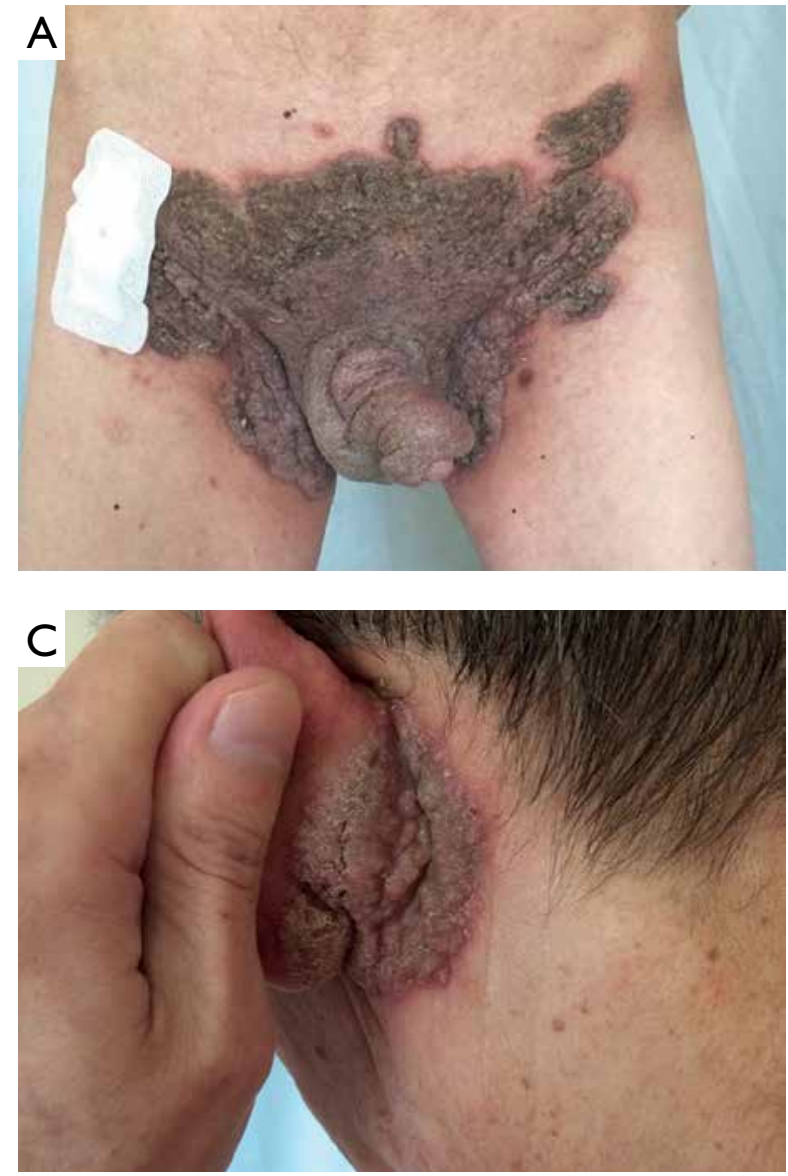

Suspecting a bullous disease with a possible association with the use of enalapril, the drug was discontinued and laboratory tests were made, revealing increased white blood cell count $(13.9 \mathrm{~K})$ and platelets $\left(463 \mathrm{~K} / \mathrm{mm}^{3}\right)$ levels and increased erythrocyte sedimentation rate $(18 \mathrm{~mm} / \mathrm{h})$. Results of other tests (electrolytes, creatinine, urea, ALT, AST, clotting parameters, fasting glucose, HBsAg, anti-HCV antibodies, HIV Ag/ Ab Combo, general urinalysis) were within their normal ranges. Ultrasound examination of the abdomen, radiography of the chest, gastroscopy and colonoscopy demonstrated no proliferative lesions nor other departures from the normal.

Immunopathological examination of a specimen collected from the occupied area demonstrated bound in vivo linear deposits of IgG in intercellular spaces of the epidermis. Immunological test using the method of indirect immunofluorescence revealed presence of pamphigus-type antibodies in the patient's serum. Histopathological examination of a specimen collected from a skin lesion, the microscopic presentation could correspond to pemphigus vegetans. Despite absence of clear acantosis, a clear epidermal hyperplasia, elongated skin papilla covered with a row of basal cells and eosinophila were present $[1,5,6]$. Besides discontinuation of enalapril, the treatment

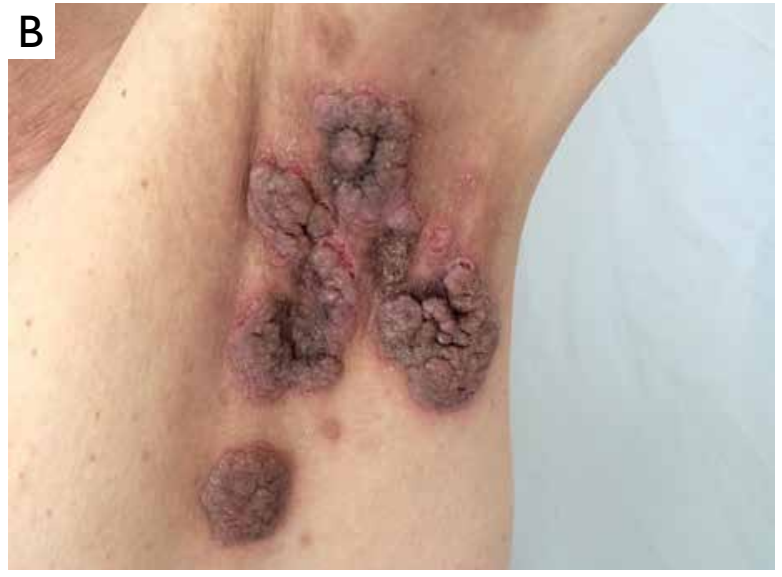

Figure I. Papillomatous hyperkeratotic lesions: A - in the anogenital region, $\mathbf{B}$ - in the axillary area, $\mathbf{C}$ - behind the ear; before introduction of treatment

Rycina I. Rozlane brodawkujące, hiperkeratotyczne wykwity: A w okolicy krocza i narządów płciowych, B - w okolicy pachowej, C - za uchem; przed włączeniem leczenia

Podejrzewając schorzenie z kręgu chorób pęcherzowych o możliwym związku z przyjmowaniem enalaprylu, odstawiono ten lek i wykonano badania laboratoryjne, w których stwierdzono podwyższony poziom leukocytów (13,9 tys.) i płytek krwi (463 tys./ mm³) oraz przyspieszone OB $(18 \mathrm{~mm} / \mathrm{h})$. Wyniki pozostałych badań (elektrolity, kreatynina, mocznik, AlAT, AspAT, parametry układu krzepnięcia, poziom glikemii na czczo, HBsAg, przeciwciała anty-HCV, HIV $\mathrm{Ag} / \mathrm{Ab}$ Combo, badanie ogólne moczu) mieściły się w normie. Badanie ultrasonograficzne jamy brzusznej, badanie radiologiczne klatki piersiowej, gastroskopia i kolonoskopia nie wykazały zmian rozrostowych ani istotnych odchyleń od stanu prawidłowego.

W badaniu immunopatologicznym wycinka z okolicy zmian stwierdzono związane in vivo linijne złogi IgG w przestrzeniach międzykomórkowych naskórka. W badaniu immunologicznym wykonanym metodą immunofluorescencji pośredniej w surowicy pacjenta wykryto przeciwciała typu pemphigus. W badaniu histopatologicznym wycinka pobranego ze zmiany skórnej obraz mikroskopowy mógł odpowiadać pęcherzycy bujającej. Mimo braku cech wyraźnej akantozy w obrazie obecna była hiperplazja naskórkowa, wydłużone brodawki skórne pokryte rzędem komórek podstawnych oraz eozynofilia $[1,5,6]$. 

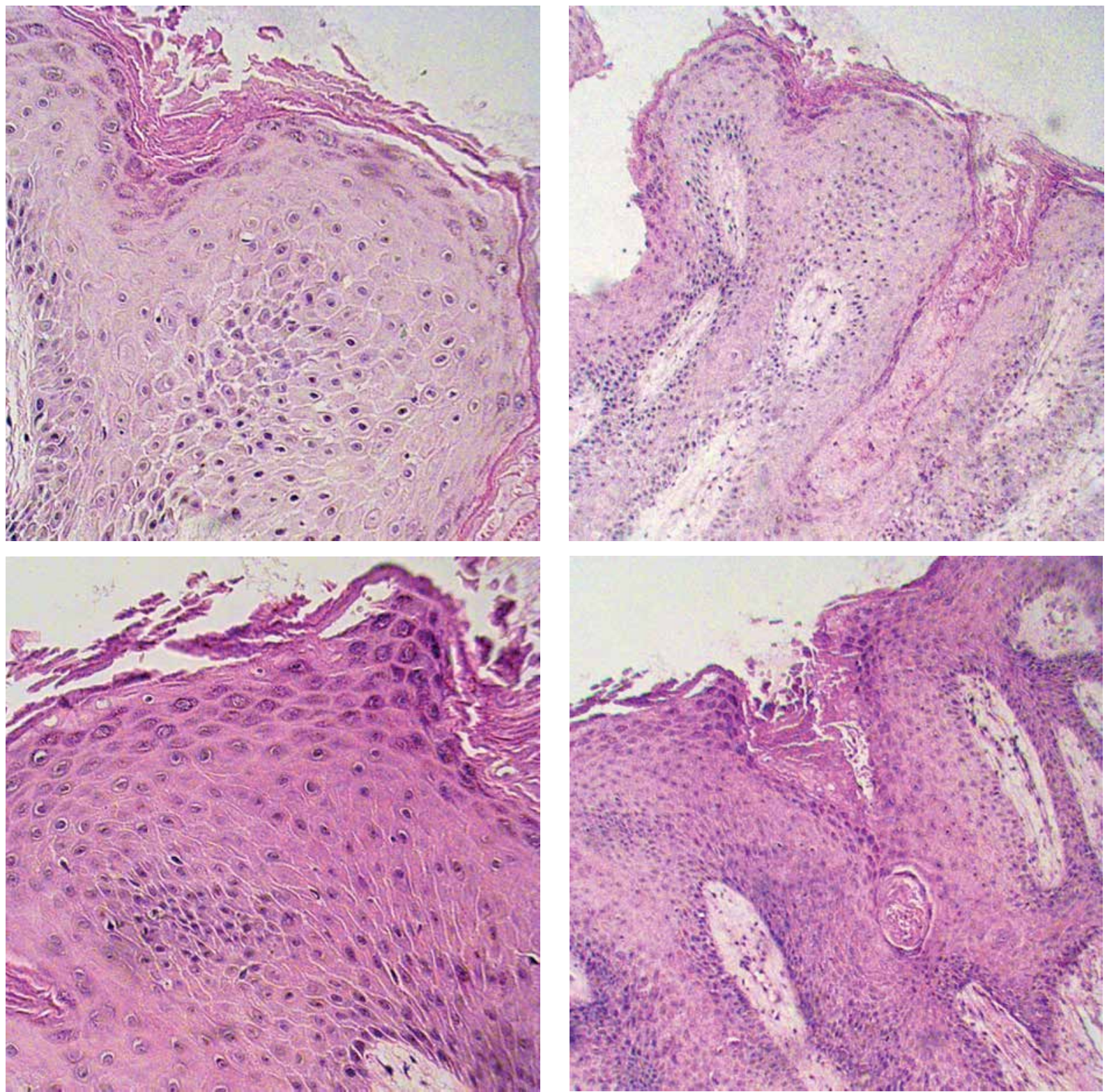

Figure 2. A specimen of the skin from the margin of the lesion in the anogenital region - epidermal hyperplasia. Eosinophils present. Elongated skin papilla covered by a single row of basal cells $[1,5,6]$. No signs of acanthosis

Rycina 2. Wycinek ze skóry gładkiej z pogranicza zmiany w okolicy krocza - hiperplazja naskórkowa. Obecne granulocyty kwasochłonne. Wydłużone brodawki skórne pokryte pojedynczym rzędem komórek podstawnych [I, 5, 6]. Brak cech akantozy

involved prednisone at the maximum dose of $2 \mathrm{mg} /$ $\mathrm{kg}$ b.w./day, subsequently gradually reduced. Glucocorticosteroid and antibiotic-containing aerosols and ointments were applied topically. The patient reacted well to the therapy. Already after a dozen or so days skin lesions begun to flatten, and purulent-erosive lesions on the smooth skin and mucosa were healed. After weeks of therapy the area occupied by pathological lesions was reduced, and the itch was alleviated. The patient was repeatedly admitted to the hospital for control investigations. The dose of prednisone was gradually reduced. After 4 months from the start of the treatment he received $50 \mathrm{mg} /$ day, and after subsequent 4 months $-20 \mathrm{mg} /$ day.
W leczeniu, poza odstawieniem enalaprylu, zastosowano prednizon w dawce maksymalnej $2 \mathrm{mg} / \mathrm{kg}$ m.c./dobę, którą stopniowo redukowano. Miejscowo zastosowano aerozole oraz maści glikokortykosteroidowe i antybiotykowe. Pacjent dobrze zareagował na terapię. Już po kilkunastu dniach zaobserwowano spłaszczenie zmian skórnych i wygojenie ropno-nadżerkowych zmian na skórze gładkiej i błonach śluzowych. Po kilkunastu tygodniach nastąpiło zmniejszenie powierzchni zajętej zmianami chorobowymi i zredukowanie świądu. Pacjent był kilkukrotnie hospitalizowany na oddziale w celu wykonania badań kontrolnych. Stopniowo redukowano dawkę prednizonu - po 4 miesiącach od początku terapii przyjmo- 

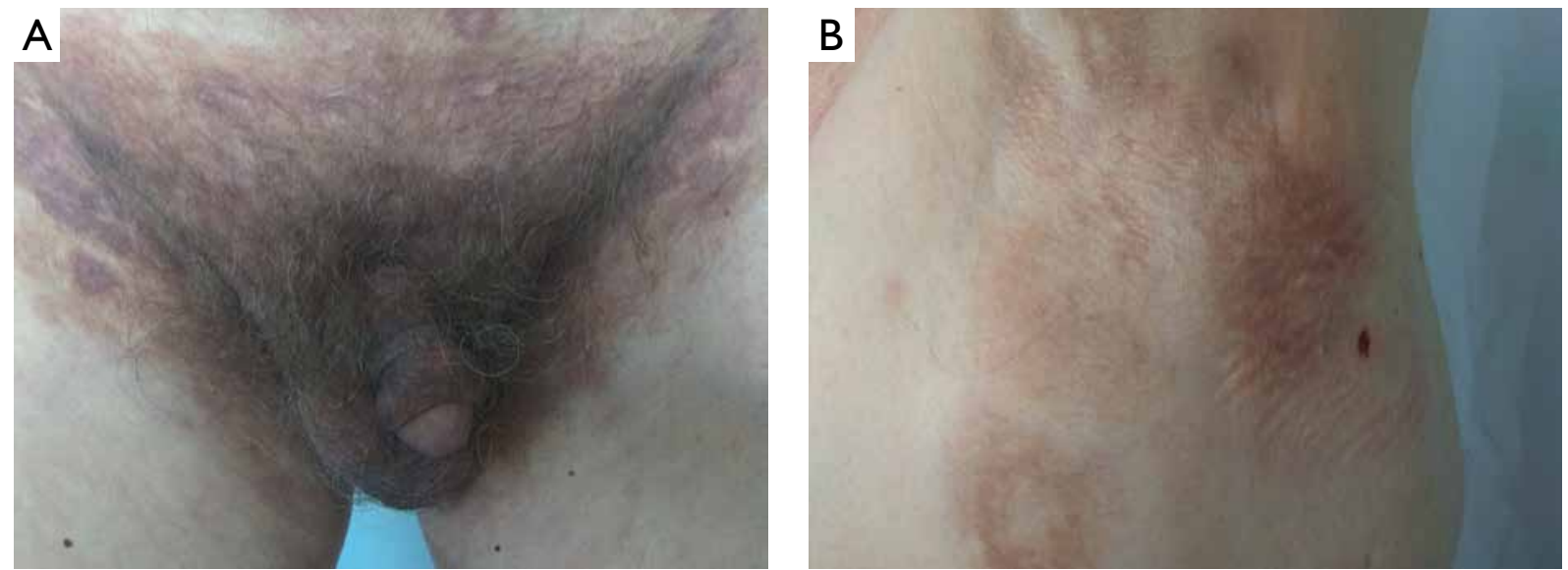

Figure 3. Post-inflammatory hyperpigmentation after several months of treatment: $\mathbf{A}$ - the anogenital region, $\mathbf{B}$ - axilary area

Rycina 3. Przebarwienia pozapalne po kilku miesiącach od włączenia leczenia: A - okolica krocza i narządów płciowych, B - okolica pachowa

Occurrence of adverse effects in course of the therapy with glucocorticosteroids lasting for 2 years, such as osteoporosis and consequential fracture of the femur, and recurrence of dermatological changes at attempt of reduction of the prednisone dose to less than $20 \mathrm{mg} /$ day, anathioprin at the dose of $50 \mathrm{mg} /$ day was introduced. The patient reacted well to the modification. At present the patient remains under supervision, with periodical control visits and laboratory tests, and the further plan of therapy involves a gradual reduction of the dose of glucocorticosteroids. Azathioprin is maintained at the dose of $50 \mathrm{mg} /$ day (fig. 3).

\section{DISCUSSION}

Pemphigus vegetans is an autoimmune disease caused by auto-antibodies against desmogleins (desmoglein 1 and 3). Desmogleins are structures responsible mainly for maintenance of intercellular adhesion in squamous epithelium of the skin and mucosa [7]. Genetic [8] and environmental factors are considered in the pathomechanism of the disease, including viruses (e.g. Herpes simplex virus), drugs, diet and stress [9]. In the presented case symptoms of the disease could be triggered by enalapril - an ACE inhibitor.

Literature mentions numerous drugs able to evoke pemphigus:

- drugs containing the thiol group (penicillamine, penicillin derivatives, thiopronin, 5-thiopiridoxine, pyritinol, piroxicam, thiamazole, sodium aurothiomalate);

- ACE inhibitors (captopril, enalapril, cylazapril, fosynopril, ramipril);

- phenolic drugs (aspirin, 5-thiopiridoxine, pyritinol, cephalosporins, rifampicin, levodopa, heroine, phenobarbital, pentachlorophenol); wał $50 \mathrm{mg}$ /dobę, po kolejnych 4 miesiącach - $20 \mathrm{mg}$ / dobę. Z powodu wystąpienia działań niepożądanych w przebiegu trwającej ok. 2 lat terapii glikokortykosteroidami, takich jak osteoporoza i w konsekwencji złamanie kości udowej, a także nawrotu zmian skórnych przy próbie redukcji dawki prednizonu poniżej $20 \mathrm{mg}$ /dobę, do leczenia dołączono azatioprynę w dawce $50 \mathrm{mg} /$ dobę. Pacjent dobrze zareagował na modyfikację leczenia. Obecnie mężczyzna jest pod stałą obserwacją, okresowo wykonywane są kontrolne badania laboratoryjne oraz planowana jest stopniowa redukcja dawki glikokortykosteroidów. Azatioprynę utrzymano w dawce 50 mg/dobę (ryc. 3).

\section{OMÓWIENIE}

Pęcherzyca bujająca jest chorobą autoimmunologiczną wywoływaną przez autoprzeciwciała skierowane przeciwko desmogleinom (desmogleina 1 i 3), które są strukturami odpowiedzialnymi przede wszystkim za utrzymywanie adhezji międzykomórkowej w nabłonku płaskim skóry i błon śluzowych [7]. W patomechanizmie pęcherzycy pod uwagę bierze się czynniki genetyczne [8] i środowiskowe, takie jak wirusy (np. wirus opryszczki pospolitej), leki, dieta oraz stres [9]. U przedstawionego pacjenta do wystąpienia objawów mógł przyczynić się enalapryl - lek należący do inhibitorów ACE.

W literaturze wymieniane są liczne leki wywołujące pęcherzycę:

- zawierające grupę tiolową (penicylamina, pochodne penicyliny, tiopronina, 5-tiopirydoksyna, pirytynol, piroksykam, tiamazol, aurotiojabłczan sodu);

- inhibitory ACE (kaptopryl, enalapryl, cylazapryl, fosynopryl, ramipryl);

- leki fenolowe (kwas acetylosalicylowy, 5-tiopirydoksyna, pirytynol, cefalosporyny, ryfampicyna, lewodopa, heroina, fenobarbital, pentachlorofenol); 
- other drugs: cytokines, propranolol, nifedipine, norfloxacin, isotretinoin, NSAIDs [3].

The discussed patient was admitted to the Ward with the diagnosis of "other local infections of skin and subcutaneous tissue". Before that he had been ineffectively treated for several months for papillous pyoderma. At the admission the extensive character of dermatological changes and the history indicating that eruptions were initially of papular character transforming into blisters, and a rapid progression of the disease suggested a more in-depth diagnostics for bullous diseases. Imaging diagnostics was ordered in order to exclude paraneoplastic pemphigus. Results discussed above and the clinical presentation clearly suggested pemphigus vegetans in form of Neumann disease.

Examples of pemphigus caused by drugs belonging to various groups are reported in literature. In the presented case enalapril is a suggested triggering agent. Drugs belonging to the same group cause different types of pemphigus. Another example of adverse effect of ACE inhibitors is reported by Makopoulos et al. pemphigus vegetans of the oral cavity, triggered by captopril [10]. Mesquita et al. and Adriano et al. presented cases of pemphigus vegetans associated with the use of enalapril [11, 12]. Bastiaens et al. report three cases of pemphigus vegetans, of which one was also triggered by enalapril [13]. Antibiotics are another group of drugs that could induce bullous diseases. Baroni et al. report a case of pemphigus vulgaris possibly associated with the use of amoxicillin and clavulanic acid [14], in another paper and the same authors report cefuroxime as a inducer of the disease [15]. An example of pemphigus caused by biologicals may be found in the paper by Hayashida et al., who indicated that the disease was triggered by secukinumab [16]. Sugita et al. and Khashoggi et al. report cases of pemphigus in patients using d-penicillamine $[17,18]$. Hur et al. presented a case of a female patient with rheumatoid arthritis and multi-muscular inflammation lasting for previous 3 years, who developed eruptions typical for pemphigus vulgaris after 20 months of the use of bucillamine. The condition was effectively managed by discontinuation of bucillamine and introduction of prednisolone [19].

The analysis of reported demographic and clinical data indicates that pemphigus affects patients at various age, including children [10, 20]. Pemphigus vulgaris is the most common type in Europe. The condition is the most common in 50-60 year old women $[21,22]$.

Treatment of pemphigus vegetans is similar to that used for pemphigus vulgaris - usually with systemic glucocorticosteroids [23, 24]. However, in the presented case no complete remission as achieved despite discontinuation of a suspected culprit medication.
- inne leki: cytokiny, propranolol, nifedypina, norfloksacyna, izotretynoina, NLPZ [3].

Przedstawiony pacjent został przyjęty na oddział z diagnozą „inne miejscowe zakażenia skóry i tkanki podskórnej”. Kilka miesięcy wcześniej był on leczony bezskutecznie z rozpoznaniem piodermii brodawkującej. W chwili przyjęcia na oddział rozległość zmian skórnych oraz wywiad wskazujący na pojawienie się początkowo wykwitów w postaci grudek przekształcających się $\mathrm{w}$ pęcherze oraz szybki postęp choroby skłoniły do pogłębienia diagnostyki w kierunku chorób pęcherzowych. W celu wykluczenia pęcherzycy paraneoplastycznej zlecono liczne badania obrazowe. Omówione powyżej wyniki i obraz kliniczny jednoznacznie wskazały na rozpoznanie pęcherzycy bujającej typu Neumanna.

W piśmiennictwie są przykłady pęcherzyc wywołanych przez leki należące do różnych grup. W przedstawionym przypadku wskazujemy enalapryl jako prawdopodobną przyczynę sprowokowania choroby. Leki z tej grupy wywołują różne rodzaje pęcherzycy. Innym przykładem działania niepożądanego inhibitorów ACE jest opisywana przez Makopoulosa i wsp. pęcherzyca bujająca jamy ustnej wywołana przez kaptopryl [10]. Mesquita i wsp. oraz Adriano i wsp. przedstawili przypadki pęcherzycy bujającej, w której zmiany skórne pojawiły się również w czasie przyjmowania enalaprylu $[11,12]$. Bastiaens i wsp. opisali trzy przypadki pęcherzycy bujającej, z których jeden został sprowokowany przez enalapryl [13]. Antybiotyki to kolejna grupa leków, które mogą indukować choroby pęcherzowe. Baroni i wsp. przedstawili przypadek pęcherzycy zwykłej o możliwym związku z przyjmowaniem amoksycyliny z kwasem klawulanowym [14], natomiast w kolejnym opracowaniu ten sam autor wymienił cefuroksym jako induktor choroby [15]. Przykład pęcherzycy wywołanej przez leki biologiczne można odnaleźć w publikacji Hayashida i wsp., którzy jako lek indukujący chorobę wskazali sekukinumab [16]. Sugita i wsp. oraz Khashoggi i wsp. opisali pęcherzycę u pacjenta przyjmującego d-penicylaminę $[17,18]$. Hur i wsp. przedstawili pacjentkę chorującą od 3 lat na reumatoidalne zapalenie stawów i zapalenie wielomięśniowe, u której po 20 miesiącach przyjmowania bucylaminy pojawiły się wykwity typowe dla pęcherzycy zwykłej, skutecznie opanowane przez odstawienie tego leku i włączenie prednizolonu [19].

Analiza danych demograficznych i klinicznych opisanych w piśmiennictwie wskazuje, że pęcherzyca występuje u pacjentów w różnym wieku, również u dzieci [10, 20]. W Europie najczęstszym typem jest pęcherzyca zwykła. Dotyczy ona głównie kobiet w wieku 50-60 lat [21, 22].

Leczenie pęcherzycy bujającej jest podobne do leczenia pęcherzycy zwykłej - najczęściej stosuje 
For that reason a decision was made to introduce the immunosuppressive medication - azathioprin. Other immunosuppresants used for treatment of pemphigus are: cyclophosphamide, cyclosporin, mofetil mycophenolate, chlorambucil and methotrexate, and antiinflammatory drugs - gold salts, dapson and tetracyclin derivatives, including nicotinamide. Immunomodulating techniques are plasmapheresis, extracorporeal photopheresis and intravenous immunoglobulins [25].

\section{CONCLUSIONS}

In the presented case, considering the patient reported introduction of enalapril several month before onset of skin eruptions, a conclusion may be drawn that the medication was a triggering agent of pemphigus vegetans. Initially the disease developed slowly and insidiously, producing symptoms resembling papillous pyroderma or dermatitis. At some point it produced a dynamically developing skin eruptions hindering the patient's everyday function. Discontinuation of enalapril and good therapeutic response to steroid therapy resulted not only in stopping the rapid development of disease, but also in a significant reduction of existing, huge eruptions. Intense itch was also reported. Despite the therapy lasting for months, the dose of prednisone could not be reduced below the level of $20 \mathrm{mg} /$ day. For that reason, a decision was made to introduce azathioprin, with hope for a complete remission.

\section{CONFLICT OF INTEREST}

The authors declare no conflict of interest. się ogólnie glikokortykosteroidy [23, 24]. Jednak w przedstawionym przez nas przypadku pomimo odstawienia leku podejrzanego o prowokowanie zmian nie uzyskano całkowitej remisji, dlatego zdecydowano o włączeniu do terapii leku immunosupresyjnego - azatiopryny. Pozostałe leki immunosupresyjne stosowane w leczeniu pęcherzycy to: cyklofosfamid, cyklosporyna, mykofenolan mofetylu, chlorambucyl i metotreksat oraz preparaty przeciwzapalne - sole złota, dapson i pochodne tetracyklin wraz z nikotynamidem. Do technik immunomodulujących należą plazmafereza, pozaustrojowa fotoforeza i immunoglobuliny stosowane dożylnie [25].

\section{WNIOSKI}

W przedstawionym przypadku po analizie wywiadu, w którym pacjent podał początek przyjmowania leku enalapryl kilka miesięcy przed pojawieniem się wykwitów skórnych, można dojść do wniosku, że powyższy lek był czynnikiem spustowym wystąpienia pęcherzycy bujającej. Choroba rozwijała się początkowo powoli i podstępnie, powodując objawy przypominające piodermię brodawkującą lub zapalenie skóry, by w pewnym momencie wywołać bardzo dynamicznie rozwijające się wykwity skórne, zaburzające normalne funkcjonowanie. Dzięki odstawieniu enalaprylu i dobrej odpowiedzi na steroidoterapię udało się nie tylko zahamować gwałtowny postęp choroby, lecz także doprowadzić do znacznej redukcji istniejących już olbrzymich wykwitów. Opanowano również intensywny świąd. Pomimo wielomiesięcznego leczenia nie udało się zredukować dawki prednizonu poniżej $20 \mathrm{mg}$ /dobę. W związku $\mathrm{z}$ tym zdecydowano o włączeniu azatiopryny, mając nadzieję na uzyskanie całkowitej remisji.

\section{KONFLIKT INTERESÓW}

Autorzy nie zgłaszają konfliktu interesów.

\section{References}

\section{Piśmiennictwo}

1. Zillikens D.: Choroby pęcherzowe autoimmunologiczne. [In:] Braun-Falco Dermatologia. W.H.C. Burgdorf, G. Plewig, H.H. Wolf, M. Landhaler (eds.) Wydawnictwo Czelej, Lublin 2017, 663-674.

2. Kowalewski C., Dmochowski M., Placek W., Waszczykowska E., Nowicki R., Flisiak I., et al.: Diagnostyka i leczenie pęcherzycy - konsensus Polskiego Towarzystwa Dermatologicznego. Przegl Dermatol 2014, 101, 147-155.

3. Dmochowski M.: Autoimmunizacyjne choroby pęcherzowe. UM Poznań, Poznań 2006, 82-83.

4. Cozzani E., Christana K., Mastrogiacomo A., Rampini P., Drosera M., Casu M, et al.: Pemphigus vegetans Neumann type with anti-desmoglein and anti-periplakin autoantibodies. Eur J Dermatol 2007, 17, 530-533.

5. R.A. Johnson, A.P. Saavedra, K. Wolff: Uwarunkowane genetycznie i nabyte choroby pęcherzowe. [In:] Atlas i zarys dermatologii klinicznej Fitzpatricka. Wydawnictwo Czelej, Lublin 2014, 89-110.

6. L. Woźniak, I. Giryn: Choroby nienowotworowe. [In:] Atlas histopatologii skóry. PZWL, Warszawa, 1987, 41-42.

7. Kasperkiewicz M., Ellebrecht C.T., Takahashi H., Yamagami J., Zillikens D., Payne A.S., et al.: Pemphigus. Nat Rev Dis Primers 2017, 3, 17026.

8. Sinha A.A.: The genetics of pemphigus. Dermatol Clin 2011, 29, 381-391. 
9. Ruocco V., Ruocco E., Lo Schiavo A., Brunetti G., Guerrera L.P., Wolf R.: Pemphigus: etiology, pathogenesis, and inducing or triggering factors: facts and controversies. Clin Dermatol 2013, 31, 374-381.

10. Markopoulos A.K., Antoniades D.Z., Zaraboukas T.: Pemphigus vegetans of the oral cavity. Int J Dermatol 2006, 45, 425-428

11. Mesquita K.C., Igreja A.C.: Pyodermatitis-pyostomatitis vegetans: a differential diagnosis of pemphigus vegetans. An Bras Dermatol 2012, 87, 339.

12. Adriano A.R., Gomes Neto A., Hamester G.R., Nunes D.H., Di Giunta G.: Pemphigus vegetans induced by use of enalapril. An Bras Dermatol 2011, 86, 1197-200.

13. Bastiaens M.T., Zwan N.V., Verschueren G.L., Stoof T.J., Nieboer C.: Three cases of pemphigus vegetans: induction by enalapril: association with internal malignancy. Int J Dermatol 1994, 33, 168-171.

14. Baroni A., Russo T., Faccenda F., Piccolo V.: Amoxicillin/clavulanic acid-induced pemphigus vulgaris: case report. Acta Dermatovenerol Croat 2012, 20, 108-111.

15. Baroni A., Puca R.V., Aiello F.S., Palla M., Faccenda F., Vozza G., et al.: Cefuroxime-induced pemphigus erythematosus in a young boy. Clin Exp Dermatol 2009, 34, 708-710.

16. Hayashida M.Z., Pinheiro J.R., Enokihara M., de Azevedo Vasconcellos M.: Biologic therapy-induced pemphigus. An Bras Dermatol 2017, 92, 591-593.

17. Sugita K., Hirokawa H., Izu K., Tokura Y.: D-penicillamine-induced pemphigus successfully treated with combination therapy of mizoribine and prednisolone. J Dermatolog Treat 2004, 15, 214-217.

18. Khashoggi M., Machet L., Perrinaud A., Brive D., Machet M.C., Maruani A., et al: D-penicillamine-induced pemphigus: changes in anti-32-2B immunostaining patterns. Ann Dermatol Venereol 2013, 140, 531-534.

19. Hur J.W., Lee C.W., Yoo D.H.: Bucillamine-induced pemphigus vulgaris in a patient with rheumatoid arthritis and polymyositis overlap syndrome. J Korean Med Sci 2006, 21, 585-587.

20. Danopoulou I., Stavropoulos P., Stratigos A., Chatziolou E., Chiou A., Georgala S., et al.: Pemphigus vegetans confined to the scalp. Int J Dermatol 2006, 45, 1008-1009.

21. Alpsoy E., Akman-Karakas A., Uzun S.: Geographic variations in epidemiology of two autoimmune bullous diseases: pemphigus and bullous pemphigoid. Arch Dermatol Res 2015, 307, 291-298.

22. Shah A.A., Seiffert-Sinha K., Sirois D., Werth V.P., Rengarajan B., Zrnchik W., et al.: Development of a disease registry for autoimmune bullous diseases: initial analysis of the pemphigus vulgaris subset. Acta Derm Venereol 2015, 95, 86-90.

23. Stanley J.R.: Pemphigus. [In:] Fitzpatrick's Dermatology in General Medicine. K. Wolff, L.A. Goldsmith, S.I. Katz, B.A. Gilchrest, A.S. Paller, D.J. Leffell (eds.). McGraw-Hill, New York 2008, 459-468.

24. Ichimiya M., Yamamoto K., Muto M.: Successful treatment of pemphigus vegetans by addition of etretinate to systemic steroids. Clin Exp Dermatol 1998, 23, 178-180.

25. Suwarsa O., Sutedja E., Dharmadji H.P., Kusuma P., Rahardja J., Hindritiani R., et al.: The rare case of pemphigus vegetans in association with malnutrition children in the multidisciplinary management. Case Rep Dermatol 2017, 9, 145-150.

Received: 7.11 .2018

Accepted: 30.03.2019

Otrzymano: 7.11.2018 r.

Zaakceptowano: 30.03.2019 r.

How to cite this article

Barasińska P., Noga N., Bergler-Czop B.S., Sazanów-Lubelski J., Pietrauszka K., Brzezińska-Wcisło L.: Pemphigus vegetans possible association with enalapril. Dermatol Rev/Przegl Dermatol 2019, 106, 321-329. DOI: https://doi.org/10.5114/dr.2019.86915. 